\title{
Um corpo em Litura
}

\author{
A body in Litura
}

Carla Andrea Lima ${ }^{1}$

Professora Adjunta no Curso de Dança do Departamento de Fotografia, Teatro e Cinema da Universidade Federal de Minas Gerais. ORCID: http://orcid.org/ 0000-0003-0398-6787 Contato: carla.andrea.mail@gmail.com em experiências artísticas vividas no Litura Coletivo de Criação e Pesquisa em Dança e Teatro especificamente nos laboratórios práticos realizados para a criação do estudo cênico "Persefonia" tendo como foco a noção de saber em fracasso.

Palavras-chave: Arte. Psicanálise. Processo de criação.

\section{ABSTRACT}

The article proposes a dialogue between art and psychoanalysis anchored in artistic experiences lived in Litura Collective of Creation and Research in Dance and Theater specifically in the practical laboratories performed for the creation of the scenic study "Persefonia" focusing on the notion of knowledge in failure.

Keywords: Art. Psychoanalysis. Creation process. 


\section{Escrever. \\ Não posso. \\ Ninguém pode. \\ É preciso dizer: não se pode. \\ E se escreve. \\ Marguerite Duras}

A sensação é de estar na pedra lascada, que opera cortes com a necessidade de sutura. E suturar a experiência na palavra não é tarefa fácil. Talvez a tarefa que se impõe como escolha forçada nesse percurso seja a de evitar falar, de evitar articular aquilo que, sentido como trivialidade, ainda insiste em pedir asilo. A condição que se impõe aqui é a do exílio, da fala de uma exilada que demanda o asilo das palavras, sempre escorregadias, sempre insuficientes. E o terror é a constatação de que essa busca pela palavra implica, no meu percurso de artista, o de perdê-las para delas fazer litura², letra33, para escavar algo que se constitui como marca daquilo que inelutavelmente me escapa. Implica ainda um certo coabitar - habitar e ser habitado pelo mundo -, também em sua trivialidade e insignificância.

Como lidar com esse ponto in-significante que, no entanto, segue operando efeitos, pedindo passagem, letra, dança? Segue demandando significância.

Sobre esse ponto, Lacan argumenta que ele se constitui como um excedente que não encontra representação na imagem- e isso inclui a imagem do corpo - deixando nela a marca de sua não-inscrição. Isso implica a produção de um resto não especularizável que constitui a imagem pela via daquilo que nela resta elidido. Trata-se, portanto, de pensar o estatuto da imagem - inclusive no tocante à imagem do corpo - a partir daquilo que nela não se presentifica a não ser como mancha e rasura. É essa razão pela qual a imagem, na visão psicanalítica, sempre carregará em seu bojo uma certa instabilidade.

Sobre essa instabilidade, Didi-Huberman propõe, em diálogo com psicanálise lacaniana, uma problematização bastante complexa dos dispositivos implicados na representação. O objetivo de Didi-Huberman é o de repensar o estatuto da imagem na obra de arte focando em suas dobras paradoxais. Nessa perspectiva, o estatuto da imagem é problematizado pelo autor como uma organização sutil e sofisticada de emaranhados que se dão a partir de uma troca recíproca entre a presença e ausência do corpo.

Nessa direção, Didi-Huberman (2010, p. 29) identifica que "o que vemos, só vale - só vive - em nossos olhos pelo que nos olha", problematizando a inelutável modalidade do visível que, na visão do
2.

Em seu texto "Lituraterra", Lacan brinca com a etimologia do título desdobrando-o em associação com o termo latino original Litura (em latim: risco, alteração, mancha e terra) com Littera (referido à letra e à palavra Literatura). Esse desdobramento indica o estatuto que Lacan irá conferir à noção de letra em seu ensino associando-a à dimensão do sulco, da rasura - rasura, porém, de nenhum traço que lhe seja anterior.

3.

Letter ganha na língua francesa e inglesa um jogo homofônico permitindo ser interpretada seja como carta, seja como letra. Lacan ainda acrescenta, para a construção da noção de letra em seu ensino, a homofonia com litter, estendendo seu sentido a lixo, dejeto, resíduo. 
autor, "só se manifesta no abrir-se em dois" num inelutável paradoxo que separa dentro de nós o que vemos daquilo que nos olha.

Essa inelutável modalidade do visível remete, por sua vez, à instabilidade da imagem tendo em vista que essa cisão, esse abrir-se em dois, instaura uma perturbação do visível. Ao presentificar-se em sua inelutável abertura, o visível acaba por deixar entrever seus fundamentos fugidios e abissais.

Tal como sinaliza Didi-Huberman (2010, p. 30): "E eis que surge a obsedante questão: quando vemos o que está diante de nós, porque uma outra coisa sempre nos olha, impondo um em, um dentro?". O autor propõe então que "devemos fechar os olhos para ver quando $o$ ato de ver nos remete, nos abre a um vazio que nos olha, nos concerne e, em certo sentido, nos constitui" (2010, p. 31).

Diante desse vazio que nos olha, Didi-Huberman (2010, p. 33) afirma que "começamos a compreender que cada coisa dada a ver, por mais exposta, por mais neutra de aparência que seja, torna-se inelutável quando uma perda a suporta [...] e, desse ponto, nos olha, nos concerne, nos persegue".

Penso então, a partir das reflexões propostas, na relação que se faz, sob a ótica psicanalítica, entre a constituição da ideia de si como corpo (que implica um contorno construído pela via da imagem) e a inelutável modalidade do visível.

Nessa perspectiva, proponho que pensemos nesse abrir-se em dois, nessa cisão que se instaura no corpo quando esse corpo nos olha em seu vazio, e, suportado pelo que nele se perde, nos concerne e nos chama de um exterior que lateja no osso. Nesse sentido, cabe ressaltar que o sujeito constrói uma ideia de si como corpo sob o peso da libra de carne perdida.

Defendo aqui que a dança, em articulação à construção lacaniana, pode ser lugar de possível despedaçamento, de um quase desaparecimento a partir do qual uma passagem, uma presença se insinua. Como se fosse necessário perder algo do corpo para que o corpo faça presença e me convoque numa espécie de terceira margem do rio. Trânsito. Passagem. Travessia. Resta perguntar de que travessia se trata aqui e que presença ela coloca em operação.

Voltemos à libra de carne e o que ela concerne nesse enovelamento que recorta e constitui o que chamamos de corpo próprio. A essa "libra de carne" Lacan associa aquilo que cai, que se perde com a captura do sujeito na rede significante e que, por sua vez, não pode ser restituído ao corpo imaginário e tampouco ao eu, a não ser como Unheimilich ${ }^{4}$ ou ainda, pela via de um gozo do qual o sujeito nada quer saber e que insiste fora de qualquer significância.

Ao se referir à libra de carne, Lacan nos coloca frente à questão do corte, que acaba por revelar a própria esquize do sujeito: "Este
4 .

Lembremo-nos de como Freud joga com a ambivalência do termo heimilich para pensar seu conceito de Unheimilich: "Em geral, somos lembrados que a palavra heimilich não deixa de ser ambígua, mas pertence a dois conjuntos de ideias que, sem serem contraditórias, ainda assim são muito diferentes: por um lado significa o que é familiar e agradável e, por outro, o que está oculto e se mantém fora de vista [...] Heimilch é, pois, uma palavra cujo significado se desenvolve em direção a uma ambivalência, até que finalmente se confunde com o seu oposto, unheimilich ". In: FREUD, Sigmund. ESB. v. XVII. Rio de Janeiro: Imago,1996, p.242-243. Dessa forma, o conceito do estranho sinaliza a possibilidade de pensarmos que a verdadeira alteridade vem daquilo que nos é mais familiar, embaralhando a divisão entre diferença e identidade, entre próximo e distante, entre eu e outro. 
momento de corte é dominado pela forma dum retalho sangrento: a libra de carne que paga a vida para fazê-la o significante dos significantes, como tal, impossível de restituir ao corpo imaginário" (LACAN, 1998, p. 636). No Seminário 10: A angústia, Lacan se referirá novamente à libra de carne situando em sua construção a questão do objeto $a$ apontado como esse algo não especularizável que cai da imagem fazendo furo. Furo que, sustenta o que conhecemos e chamamos de corpo próprio: "A libra de carne encarna esse pedaço da carne, cortado do corpo, objeto que cai, "pathos do corte", resto do "engajamento na dialética significante" (LACAN, 2005, p. 237). Existe algo do corpo que permanece como resto e, portanto, inacessível à apreensão por parte do sujeito via imagem, uma vez que:

A imagem do corpo próprio sempre guardará uma instabilidade, considerando que sua constituição implica sempre a produção de um resto não especularizável, um excedente que não encontra representação no campo da imagem unificada, deixando aí a marca de sua não inscrição. A este excedente Lacan dará o estatuto de um objeto, marcado pela estranheza já assinalada por Freud em seu estudo sobre o Unheimlich, e pelas alterações que produz ao nível da imagem, como o fato de não ser orientado, de não ser especularizável, e que ele nomeia como "objeto a" (MANDIL, 2008, p. 2).

Resta caído o objeto $a$, resultado de uma operação de perda e, portanto, significante. Resta caído fora d'isso que se encadeia num discurso, e que diz respeito a isso que não se diz, mas que, no entanto, produz efeitos, produz ato: "Objeto perdido nos diversos níveis da experiência corporal em que se produz seu corte, é ela que constitui o suporte, o substrato autêntico de toda e qualquer função de causa" (LACAN, 2005, p. 237).

Lacan, no Seminário 11, trabalha o tema do olhar afirmando que, no sonho, isso mostra sinalizando que isso diz respeito ao movimento pulsional. Ana Costa, ao revisitar o percurso lacaniano, tece elaborações sobre esse isso mostra articulado à pulsão localizando aí algo fundamental que a psicanálise sinaliza em nossa relação com o corpo:

Isso como um indeterminado - que somente adquire determinação a partir de um terceiro - representa a condição de exterioridade em que primeiro surge o movimento da pulsão. Essa "exterioridade" - esse isso estranho ao eu - sempre irá compor nossos sentimentos em relação ao corpo, nunca completamente "nosso" (COSTA, 2015, p. 30).

Desse modo, essa libra de carne excluída da cadeia significante nos causa, indicando também um limite ao saber que Lacan 
denominou uma falta a ser, ponto em que o sujeito, na sua relação consigo ou com seu corpo, não sabe nada d'Isso que o atravessa.

A imagem corporal se sustenta num ponto de fuga em torno do qual a imagem do corpo próprio se constitui. Também nessa direção se dá a construção do quadro fantasmático a partir do qual o sujeito sustenta um "saber de si". Tem-se aqui uma aproximação entre os processos de constituição de um corpo próprio com a fantasmática que sustenta nossa existência, nossa representação nesse quadro. O que interessa é sinalizar que esse quadro é sustentado por aquilo que nele resta elidido, e que nele provoca mancha, rasura. Dele desaparece o objeto que estruturou a fantasia, marcando presença a partir de uma ausência. Entretanto, cabe salientar que esse objeto não desaparece sem deixar rastros. Como diz Lacan, "[...] sempre há no corpo, em virtude desse engajamento na dialética significante, algo de separado, algo de sacrificado, algo de inerte que é a libra de carne" (LACAN, 2005, p. 242). A dimensão do não-saber se instaura tendo em vista que, diante desse furo, disso que cai, disso que goza, o sujeito segue sem saber.

Nesse sentido, tal como salienta Ana Costa (2015), o que vemos é a proposição, por parte da psicanálise, de outra relação com o saber, que traz toda a importância para situar o sujeito enovelado à experiência, uma vez que a proposta aqui é "tomar o saber a partir do insabido do inconsciente" (COSTA, 2015, p. 57). A autora esclarece que não se trata da proposição de uma "falta a saber", se tomarmos essa expressão como alguma coisa que possa ser apresentada como saber positivado no futuro, mesmo que no momento presente o sujeito não saiba. Não se trata, portanto, de algo que, desconhecido pelo sujeito, se tornaria pouco a pouco conhecido num desvelamento progressivo de si. A psicanálise, na leitura de Ana Costa, ao propor o saber inconsciente como o insabido, coloca em causa um furo no saber:

É o encontro desse furo que diz respeito à necessidade do sujeito se situar por relação ao laço instituído, na constituição ficcional que o implica a esse laço. Nesse sentido, a posição do analista diz respeito à produção desse furo no saber, que contradiz, ou mesmo destitui, toda relação com o que é evidente (COSTA, 2015, p. 57).

Pensemos então naquilo que destitui toda e-vidência. E isso também diz respeito a relação do sujeito com esse corpo estranho/ entranho, tão próximo, mas nunca inteiramente dele.

Como lidar com aquilo que, sob o peso de nos sustentar, acaba por revelar a condição mesma de nossa estrangeiridade? E com ela, esse exterior inabitado que é o corpo. Como lidar com o fato de que a constituição de si mesmo como corpo só se dá sob a 
condição de uma perda? Marcada por essa contingência, dançar para mim sempre foi operar com os efeitos daquilo que ex-iste. Daquilo que incide como uma voz estranha/entranha que sulca o corpo fazendo dele invocação, eco de lalangue, numa espécie de dança que opera na fina lâmina de um em-si porque fora-de-si. Estamos aqui diante da condição de extimidade própria à psicanálise.

Sobre o termo extimidade é importante salientar que ele se constrói articulado ao de intimidade não sendo simplesmente seu oposto porque o extimo é precisamente o íntimo, inclusive o mais íntimo. Tal como esclarece Jacques-Alain Miller: "Esta palavra indica sem embargo, que o mais íntimo está no exterior, que é como um corpo estranho" (MILLER, 2004, p. 14)

Pensemos então nesse corpo estranho, pego em ponto de queda, que por sua vez o põe em estado de perda. Para tanto, debrucemo-nos um pouco mais sobre essa voz estranha/entranha, esses ecos de lalangue que nos colocam numa dança que se opera na fina lâmina de um em-si porque fora-de-si.

Em seu texto, "O Rato no Labirinto", Lacan nos apresenta lalangue tecendo uma articulação dela com o saber. Pensando incialmente o saber como um enigma que nos é presentificado pelo inconsciente, o psicanalista associa-o, num primeiro momento, àquilo que se articula. Sabemos que Lacan parte aqui da perspectiva do inconsciente estruturado como linguagem. Entretanto, nesse texto, Lacan inaugura um novo horizonte de reflexão, quando nos adverte quanto ao caráter singular de lalangue, reforçando que ela é da ordem da transmissão.

É, portanto, nesse quadro do inconsciente estruturado como linguagem que Lacan operará uma pequena torção, ao problematizar o conceito de lalangue afirmando que: "Se eu disse que a linguagem é aquilo como o que o inconsciente é estruturado, é mesmo porque, a linguagem, de começo, ela não existe. A linguagem é o que se tenta saber concernentemente à função de lalangue" (LACAN, 1985, p. 189). Desse modo, tal como desenvolvido por mim em texto anterior, o autor apontará a linguagem como uma elocubração de saber sobre lalangue, instaurando um limite no domínio do saber, sempre marcado pela vertente do não-saber, ou se quisermos, de um saber que tangencia o Real, posto que a linguagem não o abarca a não ser sofrendo seus efeitos.

Certamente, é assim que o próprio discurso científico a aborda, exceto que lhe é difícil realizá-la plenamente, pois ele não leva em consideração o inconsciente. $\mathrm{O}$ inconsciente é o testemunho de um saber, no que em grande parte ele escapa ao ser falante. Este ser dá oportunidade de perceber até onde vão os efeitos de alíngua [lalangue], pelo seguinte, que ele apresenta toda sorte de afetos 
que restam enigmáticos. Esses afetos são o que resulta da presença de alíngua [lalangue] no que, de saber, ela articula coisas que vão muito mais longe do que o ser falante suporta de saber enunciado. A linguagem, sem dúvida, é feita de alíngua [lalangue]. É uma elucubração de saber sobre alíngua [lalangue]. Mas o inconsciente é um saber, um saber-fazer com alíngua [lalangue]. E o que se sabe fazer com alíngua ultrapassa de muito o de que podemos dar conta a título de linguagem. Alíngua nos afeta primeiro por tudo que ela comporta como efeitos que são afetos. Se se pode dizer que o inconsciente é estruturado como uma linguagem, é no que os efeitos de alíngua, que já estão lá como saber, vão bem além de tudo que o ser que fala é suscetível de enunciar (LACAN, 1985 [1973], p. 189-190).

Lalangue - enxame (essaim) de significantes-mestres (S1) (LACAN, 1985 [1973], p. 196) com os quais o infans entrou em contato antes de ser capaz de entender suas significações e que permanecem como impressões que marcam seu corpo. O que é importante salientar é que esses significantes são indissociáveis do gozo e que eles não se encadeiam entre si.

Nessa perspectiva, lalangue tem a ver com aquilo do inconsciente que, jamais interpretado, gera efeitos disruptivos sobre a linguagem. De modo que podemos tecer uma articulação de lalangue com essa dança que opera na fina lâmina de um em-si porque fora-de-si posto que é do corpo que se trata, disso que no corpo resta como chamado mudo que grita. Foi o trabalho sobre esses traços, esses restos que não totalizam um saber de si - ou ainda um saber sobre o corpo - que chamei de queda do corpo no corpo, posto que ela põe em operação um trabalho sobre si que é trabalho sobre o corpo, ou seja, um trabalho sobre aquilo que no corpo resta sem origem, porque sem inscrição significante, em sua vertente de Real, uma vez que esta resta silenciosa, só se dando a ver por meio de seus efeitos disruptivos, efeitos que denotam um universo afetivo e pulsional que persiste enigmático.

Tal queda é ocasionada por um atravessamento do fora que acaba por colocar em xeque, em ponto de perda, nossas ideias arraigadas acerca do corpo e porque não, de dança.

Hijikata pergunta:

O que aconteceria se fosse possível colocar uma escada dentro do corpo para descer até o fundo? Há um ponto, na profundidade sem medida, em que o visível se deteriora. A dança poderia existir para rejeitar este estado interno do corpo? E caso fosse possível fazer isso, seria, finalmente identificável que o olho não serve só para ver, a mão não foi feita exclusivamente para tocar e todos os órgãos não podem ser restritos às suas funções e organizações? Como se começa o que não tem filiação e apenas se alimenta dos abjetos do mundo? (HIJIKATA apud GREINER, 2005, p. 4) 
Tomemos essa travessia muito particular em direção a esse algo que se precipita no corpo como um chamado de fora na forma de uma queda. Importa esclarecer de que chamado se trata, posto que o que dele resulta é a queda que chamei em texto anterior ${ }^{5} \mathrm{de}$ uma queda do corpo no corpo.

Voltemos então na pedra lascada. Pensemos nessa lasca perdida que pede sutura, endereçamento e ainda uma amarração. Pede laço?

D'Isso, que não é certo, mas certeiro, sabemos que nos chega pela via da queda, desestabilizando os referenciais do sujeito, assim como sua relação com seu corpo. Nesse ponto de queda, ponto de borda, constata-se o caráter extimo desses objetos que sulcam /fundam um corpo na relação com o Outro e que Lacan nomeou objetos da pulsão. Sobre os objetos da pulsão, Lacan os situa como "testemunhas do sacrifício implicado na queda do objeto", a libra de carne. O que caracteriza esses objetos é o fato de serem amboceptivos, se constituírem como um entre, de não pertencerem nem bem à mãe, nem bem à criança. Olhar, seio, voz, fezes... Objetos que se constituem na borda com um outro...

Lembremos a passagem em que Maria Rita Kehl discorre sobre as relações entre corpo, pulsão e saber:

o que passa pelo corpo, na relação entre duas pessoas, é a constituição dos objetos pulsionais onde o corpo faz borda, abertura para o contato com o outro; é onde o corpo se abre que a pulsão circula, não no circuito fechado dos limites do eu/imagem, mas no circuito que se estabelece entre o sujeito e o Outro - primordialmente - e entre o sujeito e os outros. Se a pulsão circula onde há furo, do mesmo modo o saber se transmite onde há falha (KEHL, 2001, p. 14).

Cabe então, nessa relação que se estabelece entre corpo e saber lançarmo-nos na reflexão de que a construção de saber sobre o corpo inclui em seu tecido o lidar com esse caráter extimo do corpo.

Defendo que é a partir desse lugar extimo que podemos construir um saber sobre o corpo que não se constitua nos limites do eu e da imagem corporal. Saber que se dá a partir da circulação pulsional entre os corpos.

A produção em arte, quando convocada por esse caráter extimo do sujeito se avizinha do que Cassiano Quilici (2015) nomeou de "A Experiência da Não Forma" que se constitui como experiência ímpar, que emerge nas lacunas e fissuras do simbólico, flutuando numa região de incertezas, de opacidade. De modo que poderíamos considerar que essa experiência da não forma implica o testemunho de uma certa opacidade.
Trabalhei de forma bastante intensa sobre essa ideia de queda do corpo no corpo em articulação com a psicanálise em minha tese de doutorado intitulada "Corpo, pulsão e vazio: uma poética da corporeidade" (2012). 
Uma outra questão apontada por Quilici é que isso que emerge nas lacunas e fissuras do simbólico "tende a ser ignorado e esquecido". Esse tipo particular de experiência aparece, portanto, como "uma abertura para o que não cai nas malhas da representação", o que se desloca para fora das percepções "construídas e interpretadas segundo padrões habituais aprendidos e herdados" (QUILICI, 2015, p. 120-121).

À questão da extimidade relacionada a produção do saber soma-se outra questão que circunscreve as relações que aqui se estabelecem e que dizem respeito à relação entre dois campos: o da arte e da psicanálise. Trata-se do estabelecimento de um litoral entre esses dois campos, tal como Lacan o formula em seu texto "Lituraterra" (2003), e que contêm a referência a elementos heterogêneos, lá onde o cruzamento de limites demonstra uma não continuidade. Tal como salienta Ana Costa: "O cruzamento de um litoral requer invenções para que se dê a sustentação em um novo elemento" (COSTA, 2015, p. 19). Não se trata, portanto, de "aprender a falar uma outra língua", nem tampouco da mera aplicação de um saber sobre o outro. Desse modo, o que se busca aqui é o encontro entre heterogêneos, transitando moebianamente na relação da arte com a psicanálise e levando em conta que, nessa torção, opera-se com a diferença como espaço de potência.

Ana Costa se pergunta: "Como estabelecer relações com campos distintos mantendo-se a condição de extimidade, própria da psicanálise? " (COSTA, 2015, p. 19). Questão que não é estranha a algumas produções em arte.

Caminho esse escolhido aqui.

\section{A Litura, o Litura}

Ao me deparar com uma escrita a mim endereçada me dei conta da necessidade de construir uma reflexão sobre isso que, instituído como espaço de travessia, pede sustentação, borda, contorno. Sabemos que a escrita, para a psicanálise, mais do que uma forma de descrição, é acomodação de restos. Esse ato se constitui como uma tentativa de dar contorno, de construir marcação nisso que resta sem inscrição ou origem.

Constato que essa carta a mim endereçada chega a seu destino no momento em que me encontra como suporte. Ou seja, uma carta chega a seu destino no momento em que encontra um "leitor". Se a escrita, tal como sinalizou Lacan, é acomodação de restos, a leitura, para a psicanálise, mais que decifração, é feita de reconhecimento desses traços (DUNKER, 2015). Disso depreende-se que o que se tangencia no endereçamento dessa carta/letra é a produção de uma 
escrita. Sobre a escrita é importante não perder de vista que ela se dá nessa dupla vertente: por um lado é acomodação de restos e por outro, necessidade de inscrição (de traços, de marcas, de significantes) que necessita do encontro, de alguém que dê suporte, que sustente, pela via do corpo, o que essa escrita endereça e coloca em operação que não se restringe ao que ela diz, mas ao que ela opera.

Faz-se necessário situarmos de que endereçamento se trata, quando da entrega/recepção dessa carta/letra, uma vez que aqui uma nova organização se faz tendo em vista a destinação. Destinação esta que aposta na construção de saber alimentada pela prática artística, ao longo de 7 anos.

Para além do endereçamento da carta/letra que me foi confiada, faz-se necessário não perder de vista que ela se apoia num laço anteriormente construído, que diz de uma experiência e de uma forma de transmiti-la. Tal laço situa-se num espaço de encontro nomeado primeiramente "Litura - mapeamentos poéticos do corpo-afeto", grupo de pesquisa que se iniciou em minha pesquisa de doutorado e, quando do fim dela, se transformou num coletivo de pesquisa e criação artísticas que hoje constitui um braço do Laboratório de Práticas e Poéticas Corporais coordenado por mim na Universidade Federal de Minas Gerais e que hoje denomina Litura Coletivo de Criação e Pesquisa em Dança e Teatro.

Retomando, Ana Costa (2015) ao tratar a questão da escrita afirma que ela cria um outro real, responsável pela produção de bordas que inscrevem a letra no buraco de um saber situado em cada campo. São essas bordas que caracterizarão esse encontro de heterogêneos próprios do litoral sendo que a letra designa um elemento mínimo não comandado pelo sentido e que permite o movimento de criação, seja nas fórmulas científicas, seja no ato do artista.

Pergunto-me então, sobre essas diferentes formas de fazer laço e dele construir um registro ou ainda uma produção. Penso na arte e no seu movimento de produção de saber assim como na especificidade que constitui essa inscrição. Me remeto especificamente à construção de saber que se deu no Litura e que teve como consequência não a produção de textos que buscavam metodologizar um caminho descrevendo diferentes práticas ou procedimentos, mas o que prefiro chamar aqui, em articulação com a psicanálise, de cartas/letra, tendo em vista a intuição de que algo para além desse caráter descritivo da experiência, se inscreve. Algo da ordem da transmissão, que comporta um saber fazer com lalangue, ou seja, uma transmissão que se dá a partir do não dito, do que escapa à ordem significante sendo a letra aqui, um contorno, uma marca que ao contrário de fazer suplência a essa ausência, a marca sob a forma de um traço, de um contorno que ao contrário de suplantar, 
contorna o furo. É por isso que Lacan sinaliza a letra como litoral entre Simbólico e Real.

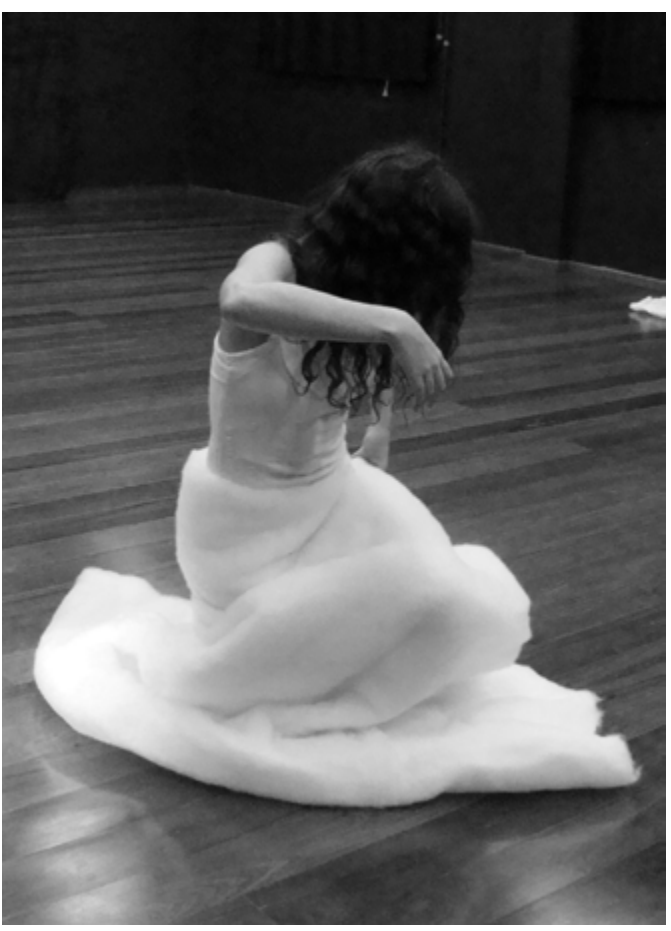

Figura 1.

Foto de Christiana Quady para o laboratório prático "Um quarto para si" do Litura Coletivo de Criação e Pesquisa em Dança e Teatro. Na foto: Carla Andrea Silva Lima.

Esse debruçar sobre as escritas do Litura tomando sua articulação à dimensão da letra ainda é trabalho a ser feito e não nos aprofundaremos numa análise vertical desse material aqui.

O que interessa, como início de percurso, é pesar de que modo essa produção realiza uma inscrição (que se trata da inscrição da letra num determinado campo discursivo). Por conseguinte, o foco nesse ponto incide sobre a amarração que se dá entre uma produção de saber específica do campo da arte e o ato de produção que se constrói exatamente quando esse saber recorta um horizonte de experiência do sujeito que fura esse saber constituído construindo nele borda. Tal como sinaliza Ana Costa: "Não se trata exclusivamente de uma questão de conhecimento, mas de posição na transmissão desse saber. A posição daquele que produz seu ato o implica uma busca de inscrição específica no discurso, recortando, dessa forma, um saber na linguagem" (COSTA, 2015, p. 64).

É preciso, portanto, não perder de vista esse endereçamento que se configura como uma pergunta sobre um saber que ultrapassa o sujeito. Minha aposta é que, nesse endereçamento, indaga-se algo sobre o saber em arte recolocando determinadas questões que têm por base essa posição intervalar - de exílio e determinação - em que se encontra o sujeito em sua relação com o saber.

Nesse sentindo, faz-se importante situar o estatuto do saber, tal como a psicanálise o recorta, uma vez que ele difere do 
conhecimento não se assemelhando a um conteúdo ideativo, algo que pode permanecer como uma representação exterior à experiência; fora de nós, objetivável e passível de ser assimilado pelo entendimento. Na dimensão psicanalítica não se trata de um saber do qual se possa vir a ter um conhecimento assimilável pelo sujeito, haja vista que ele carrega uma dimensão de ignorância. Trata-se da produção de algo que se faz na experiência. Convém ressaltar, entretanto, que o saber da experiência não garante que o sujeito "conheça" o que sua experiência representa.

A experiência não deve ser pensada nessa acepção como redutível à esfera do conhecimento ou ainda referida a um símbolo abstrato tendo em vista que é necessária sua passagem pelo corpo e se fazer na relação com o Outro e com o Real:

É somente essa natureza mais extensa da experiência que produz um registro que a teoria lacaniana denominou de saber. Como se pode depreender, o saber aqui se diferencia da informação e do conhecimento, na medida em que ele é necessariamente corporal e, também inconsciente (COSTA, 2001, p. 33).

A esfera do saber, para Lacan, é conjugada à do registro, de algo que permanece impresso a partir de uma experiência, corporal e inconsciente, como traço obliterado, apagado e que, no entanto, repete, insiste em ato revelando sua dimensão de furo.

No Litura tínhamos que conviver com ressonâncias de experiências que jogavam a partida do silêncio, desestabilizavam percursos, enlutavam um saber, na medida em que, diante de coisas que escapavam - seja porque nelas não encontrávamos palavras, seja porque não cabiam na dimensão do recorte dos nossos olhos ou seja ainda porque o cair em si era contingência de uma perda -, jogar essa partida exigia conviver com certa dimensão intermediária entre o que se constata e o que não se deixa pegar. Destarte, a experiência que se circunscrevia no Litura convidava-nos a aprender a testemunhar uma determinada opacidade.

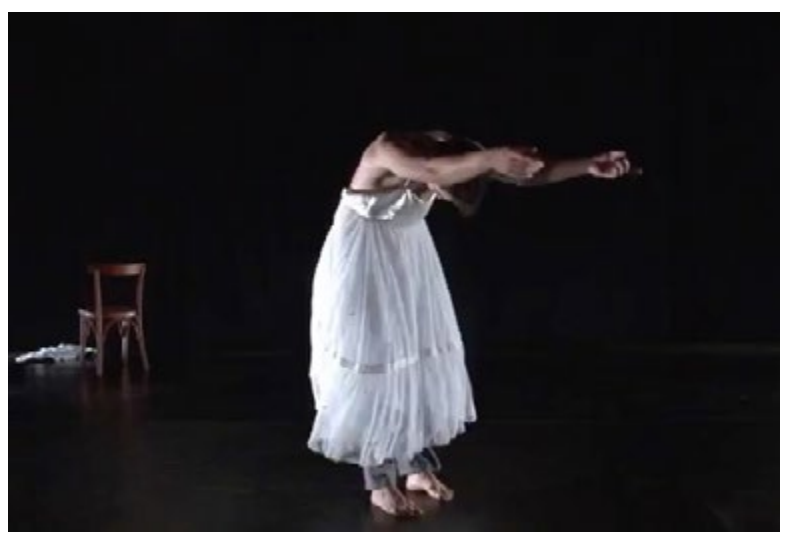

Figura 2.

SILET (2014). Solo de Gui Augusto dirigido por mim e elaborado em laboratórios do Litura Coletivo de Criação e Pesquisa em Dança e Teatro. Foto: Carla Andrea Silva Lima. Na foto: Gui Augusto. 
Sabemos do nome que ele não traz sentido, mas "cava um lugar" (COSTA, 2015, p. 33).

Tomemos esse nome Litura, que pode ser tomado como "parte ilegível de um escrito por efeito de rasura" e percebamos que esse ato de nomeação já cava, desde sua fundação, um lugar que recoloca esse apelo exilado numa relação com o saber.

Essa carta/letra endereça a mim, em seu desamparo, que difícil mesmo é amar as coisas triviais, aquelas que são coisas por si mesmas, pois dessas não nos vem qualquer promessa. A contradição aí vista vem da constatação de que, exatamente essas coisas, que não carregam qualquer promessa e que apenas se apresentam em sua coisidade, são as mais necessárias à vida. E nisso consiste o que meu parceiro de Litura, Gui Augusto, chamou de "banalidade trágica, irritantemente irresolvível". Essa banalidade se dá não porque os olhos não conseguem ver o que ali se revela e ressoa como acontecimento "incômodo", mas porque os olhos enxergam o reflexo do que está em jogo no ato de olhar revelando a cisão existente entre ver e olhar. Por isso, talvez, indaga ele, a sensação seja horrorosa, essa da observância, porque olhamos nosso próprio buraco, isolamento.

A banalidade trágica das coisas, isso que nos escapa em função de sua in-significância, nos olha, nos fita e nos concerne fazendo desse buraco - lugar de exílio e perda - um chamado. Chamado que implica um habitar o mundo tendo que lidar exatamente com sua coisidade, com aquilo que banal, singelo, evidente acaba por escapar aos olhos ou por atravessá-los com tamanha leveza que a própria leveza, tal como um dia nos alertou Milan Kundera, se torna insustentável:

Se o eterno retorno é o mais pesado dos fardos, nossas vidas, sobre esse pano de fundo, podem aparecer em toda sua esplêndida leveza. Mas, na verdade, será atroz o peso e bela a leveza? O mais pesado fardo nos esmaga, nos faz dobrar sobre ele, nos esmaga contra o chão. Quanto mais pesado o fardo, mais próxima da terra está nossa vida, e mais ela é real e verdadeira. [...]. Por outro lado, a ausência total de fardo faz com que o ser humano se torne mais leve que o ar, com que ele voe, se distancie da terra, do ser terrestre, faz com que ele se torne semirreal, que seus movimentos sejam tão livres quanto insignificantes. Então, o que escolher? O peso ou a leveza? [...]. Parmênides respondia: o leve é positivo, o pesado negativo. Teria ou não razão? Essa é a questão. Uma coisa é certa. A contradição pesado-leve é a mais misteriosa e mais ambígua de todas as contradições. (KUNDERA, 1985, p. 11).

A torção que se opera aqui na construção de Kundera nos parece essencial, uma vez que, nisso que retorna, que se repete 
pedindo inscrição, o peso abandona sua condição de insustentável e a leveza, de espaço de liberdade. Faz-se necessário frisar que essa torção é condição dessa pedra lascada que pede sutura, amarração. O importante é não perder de vista que essa amarração é da ordem de um enlaçamento singular feito por aquele que, habitante dessa condição de exilado, dirige a alguém um chamado ou melhor, interpela: quem me chama nesse que chamo? O que nos interessa é aproximarmo-nos desse singular que caracteriza a produção artística, do endereçamento que ela comporta assim como a especificidade da produção de saber implicada aqui.

Nesse retorno é necessário pensar no corte que opera uma torção e que, numa operação moebiana, faz do peso marca de existência, amarração que circunscreve um lugar a partir do qual o sujeito se reconhece e se nomeia tendo como base um campo de saber. Na outra ponta do laço, Kundera nos apresenta a leveza, que nos deixa num exercício de liberdade que se confunde com um desamparo primeiro, intolerável e irremediável, uma vez que essa leveza se confunde com a incidência de algo que nos atravessa sem que dele consigamos fazer registro. É nessa figuração que a leveza pode se tornar insuportável e, por sua vez, insustentável.

O fato, sinaliza Juliano Pessanha, é que o "sujeito já aparece encenado e inscrito (lançado) numa trama pré-fabricada" (PESSANHA, 2015, p. 65) estando destinado a circunscrever um si-mesmo sempre a partir de seu assujeitamento, por meio da mediação de um recorte uma vez que essa "cota de alienação", tal como o autor a chama, não pode ser desfeita, haja vista que ela é constitutiva da realidade do sujeito, condição para que ele possa habitar o dentro do mundo. Esta condição, diz Pessanha, nos revela que "o homem não se inventa ex-nihilo mas que, quando dá por si, já está inventado e já foi 'preenchido' por algo de que não dispõe" (PESSANHA, 2015, p. 65). Interessante essa construção na qual o autor alinha o "dá por si" (tal como um cair em si) a uma condição de ser habitado por um outro. Ou ainda, a uma constatação de um fora de si que carrega a construção de toda subjetividade. "Se sou, é porque fui lançado e encenado por um outro, de tal modo que o que me funda, está fora de mim" (PESSANHA, 2015, p. 65). A isso o autor chama o "peso específico do mundo", irresistível em seu poder de atração. De modo que conclui que aqui não se trata simplesmente do vínculo, mas da ligação ao vínculo.

Entretanto, isso significa também que "o fio que me liga ao que sou pode se quebrar e, se o homem é o espelho das encenações que o tecem, esse espelho pode ficar desabitado, de tal modo que o sujeito se vê exilado de si mesmo e trazido até a distância dos 'materiais' que ousaram 'povoá-lo'” (PESSANHA, 2015, p. 66). 
De modo que o desenraizamento revela a face de sua insustentável leveza, tendo em vista que habitar o mundo em sua coisidade só se faz sobre a égide de perdê-lo assim como o saber que o sustenta.

\section{A insignificância}

\section{É necessário certo grau de cegueira para poder enxergar determinadas coisas. É essa talvez a marca do artista. Qualquer homem pode saber mais do que ele $e$ raciocinar com segurança, segundo a verdade. Mas exatamente aquelas coisas escapam à luz acesa. \\ Clarice Lispector}

Detenhamo-nos à epigrafe de Clarice Lispector, e com ela sigamos essa afirmação de que ao artista, cabe se ocupar das coisas que escapam à luz acesa. De modo que pensaríamos que o movimento da escrita clariceana comporta um saber fazer com aquilo que escapa à claridade, uma vez que mostrar demais também é uma forma de esconder.

Em janeiro de 1977, na revista Les cahiers du chemin, Foucault publica o texto "A vida dos homens infames" cujo cerne incide sobre casos de vidas desordenadas, indocilizáveis e obscurecidas. Assim sinaliza Julia Naidin, a respeito da construção foucaultiana:

Se, em um primeiro sentido, a linguagem e a organização dos modos de vida possuem uma função de expressão que nos caberia decifrar, como uma marca velada pela superfície dos discursos, o que vemos nesses personagens são acontecimentos esquecidos e abafados. Vidas efêmeras de homens e mulheres que, em razão da obscuridade e do silêncio atribuído às suas condições bizarras de impossibilidade de conciliação entre vida e discurso, só tiveram suas existências registradas porque, em algum momento, por uma convergência de acasos, cruzaram-se com um regime de poder e criaram uma faísca em sua pretensa limpidez. (NAIDIN, 2016, p. 1035)

O fato é que, ainda seguindo a construção proposta por Naidin, tais vidas nos informam sobre nós. A palavra "Nós", neste sentido, não deve ser entendida simplesmente como um agrupamento de pessoas reunidas sob uma doutrina, tradição ou comunidade, mas também sobre nossas próprias normas, fascismos e intolerâncias. Por esse viés podemos nos colocar em movimento pensando que, nessas vidas infames que nos informam sobre nós, um outro endereçamento se faz, convocando-nos e desestabilizando nossos modus operandi assim como a maneira como nos relacionamos com o Outro e com o saber.

O que Foucault faz é inquietar nosso olhar. Ele busca, tal como 
frisa Naidin (2016) justamente o sentimento de "sem lugar", de um unheimilich que instaura um espaço para a criação e proliferação de outros modos de existência. Ao tocar nessas vidas infames dando a elas um corpo pela escrita é esse "sem lugar" que Foucault nos apresenta e é nesse "sem lugar" que ele nos coloca. São vozes que revelam uma crise, chamados que criam fissura em um determinado modo de ver coisas por meio de uma vivência particular, que faz inscrição, furo no saber antes constituído e legitimado. Tais vidas, ao serem nomeadas cavam também um lugar pela via da escrita foucaultiana, e cria, por seu próprio acontecimento "outras formas de prazer, de ver, novas necessidades de relação, novas séries de coexistência, outros tipos de laço, [...] novos tipos de cuidado, fora das matrizes da taxonomia e da normatização moral" (NAIDIN, 2016, p. 1036).

O que se tangencia aqui é da ordem da escuta do que, julgado como sem importância (se tomamos como referência esse olhar internalizado do outro que captura e inquire), insiste como lâmina cega. Como aquilo que, bobo de dizer, no entanto insiste em ser dito. Insiste como um aguilhão que traz algo do vivido, mas, no entanto, faz-nos esgarçar o próprio tecido da vida a ponto de não sabermos mais a fronteira que separa o grito da força que ele comporta.

$E ́$ a isso que se quer sempre, insistentemente tentar dizer, que dirijo meu apelo, sabendo que esse apelo será sempre a produção de um saber em fracasso ou, como queria Lacan, um saber em abismo.

Sobre esse saber Lacan dirá, em seu texto "Lituraterra", que é aí que a psicanálise mostra o que tem de melhor. Saber em fracasso como se diz figura em abismo, no que Lacan adverte que isso não quer dizer fracasso do saber (LACAN, 2003).

Há aqui, tal qual nos adverte Éric Laurent (2010), um ponto referente ao método tendo em vista que o psicanalista aborda tudo do ponto de vista do fracasso: o ato falho, o ato sintomático, a coisa que manca. "Sobre as coisas que têm sucesso", adverte Laurent, "o psicanalista não tem muita coisa para dizer" (LAURENT, 2010, p. 99). Entretanto, convém ressaltar que o autor faz elogio de certa modalidade de fracasso. De um tipo de fracasso, tal como sinaliza Lucíola Freitas Macêdo (2012) que não tem o sucesso como oposto complementar. Trata-se, portanto, de um fracasso sem par.

Nessa direção, o saber em fracasso se configuraria como um anti-método, uma vez que se debruça nas exceções, ou melhor, no que excede; nas quedas, dobras e reentrâncias daquilo que se constrói como produção de sentido causando nesse uma refração e também uma recalcitrância, dizendo respeito principalmente àquilo que faz corte, que fratura.

Tendo em vista o contexto em que me encontro, da pedra las- 
cada, da necessidade de suturar algo que visita atravessando a carne, como marca no corpo impossível de fazer sentido, talvez seja fundamental retomar, no percurso dessa escrita, a constatação de Lacan: a psicanálise prospera no fracasso. E essa será aqui a minha tentativa. De um certo prosperar naquilo que se considera tropeço, sem importância, ou mesmo frágil. o que implica, portanto, o reconhecimento da vã tentativa de remediar o precário, e mesmo a inconsistência dos operadores que agora constituem meu percurso, o percurso de artista, por meio do saber constituído, mesmo de um saber constituído no âmbito da própria arte ou ainda da psicanálise. Não se trata aqui tampouco de demonizar o saber constituído em prol de uma certa pureza original. Sabemos bem a que tipo de atos bárbaros essa pretensão de pureza original pode nos levar. Convém aqui abrir um parêntesis para ressaltar que o que venho convocar concerne uma determinada forma de operar e mesmo de fracassar no tocante ao saber. Trata-se, portanto, de reconhecer o saber como uma espécie de dispositivo que poderá instaurar uma hiância em dado momento ou circunstância e vir a funcionar como tampão no momento seguinte.

"A psicanálise prospera no fracasso". Como entender tal assertiva de modo a não incorrer em uma apologia ao insucesso, como bem nos adverte Elisa Alvarenga (2003) e Lucíola Freitas Macedo (2012). Nessa perspectiva, com a ajuda dessas autoras, vai se rasurando para mim o ponto, obliterado e insistente, que me interessa contornar aqui. Entretanto sinalizo que a tentativa desse contorno não tem qualquer pretensão de captura. Seguiremos essas autoras na proposição de certa diferença, pois elas localizam uma nova implicação do fracasso: o fracasso do sentido no tocante ao gozo, uma vez que esse sentido não dá conta de capturá-lo na rede significante, posto que o que está em jogo no gozo é da ordem de um acontecimento de corpo.

Penso então que, sem esse fracasso, denominado por mim de queda do corpo no corpo, não se produziria também dança, ou pelo menos não se produziria essa dança que, deixando de se interrogar sobre o como se move passa a nos interpelar com a pergunta: O que te move?

Miller se pergunta: O que fracassa com o fracasso do sentido? (MILLER apud MACÊDO, 2012, p. 4). Ao que ele responde: a ontologia, enquanto discurso do ser. Na transferência fracassa o amor, em sua vertente narcísica. Também fracassa o saber como doação de sentido. Destarte temos aqui uma relação apontada entre saber em fracasso, ser e sentido. Nesse passo Macêdo sinaliza que a existência não nos faz sair da linguagem, mas que para ter acesso a ela - que indica, a meu ver, uma tomada de posição diante disso que 
nos atravessa e que nos alija cavando um lugar, uma inscrição - é preciso tomar a linguagem em outro nível que não apenas o do ser. Tomar a linguagem em outro nível que não o do ser é tomá-la em sua dimensão de letra, ao nível da escrita, "não da escrita da fala, da semântica dos sintomas, que produz múltiplos sentidos, mas da escrita como manejo da letra, do rastro, do significante quando este opera em sua dimensão de furo, ressoando no corpo como um acontecimento" (MACÊDO, 2012, p. 5).

Tal assertiva abre espaço para pensar que se discorre aqui sobre uma outra transmissão de saber que não se dá pela via do sentido. Trata-se de pensar a transmissão pela via de um esvaziamento de sentido, daquilo que, não fazendo série na cadeia significante, opera nos vazios que a escrita contorna marcando um lugar não em seu caráter representativo, mas como acomodação de traços, restos - letra. Nessa perspectiva, o significante não opera em sua vertente de conexão com o significado, e sim conectado à pulsão. Na dança, essa conexão se revela nos interstícios do corpo... de cacos de gestos, de sensações fragmentárias, cacos de coisas que não se deixam abarcar, permanecendo escorregadias, de modo que diante delas faz-se necessário mal ver, mal dizer. Até, quem sabe, mal dançar.

Retomemos a frase de Lacan: "Saber em fracasso não quer dizer fracasso do saber". Desse modo, o saber em fracasso é uma forma de produção de saber que estabelece relações com o insabido, com o fragmentário, com aquilo que, lacunar, insiste como furo, pedindo inscrição, contorno, borda.

Os espaços de borda num dançar enlutado

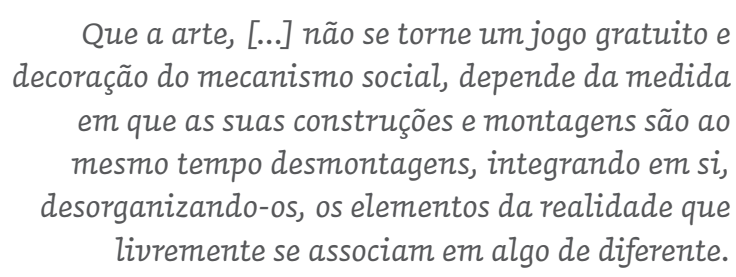

Adorno

"Minha história terminada, ainda vou estar vivendo. Falta que promete. É o fim de mim. Não vou mais dizer eu" (BECKETT, 1986, p. 137).

"Minha vida começa pelo meio, como eu sempre começo pelo meio, aí vai o meio. Depois o princípio aparecerá ou não". Faz-se necessário aqui pensar com Clarice Lispector que, como a vida, toda a escrita começa pelo meio na tentativa de que por ele se possa esboçar, numa ficção de si (que já é uma desconstrução de si), um começo ou um fim. 
O meio, pelo qual começo agora, diz respeito a um poema de Manuel de Barros que me disse:

E, aquele

Que não morou nunca em seus próprios abismos

Nem andou em promiscuidade com os seus fantasmas

Não foi marcado. Não será exposto

Às fraquezas, ao desalento, ao amor, ao poema”

Esse poema me ressoou por tempos: o abismo, a fantasia, a promiscuidade com aquilo que, fantasmático, vela e revela uma causa a ser. A marca, o estar exposto, o desalento, a inscrição, o poema. Ficarei em pé para dançar? Me reconheci nesse intervalo de sentido que fez em mim essa fala. E nesse intervalo algo se elidia, me fazia pequena, inerte, paralítica. Ficarei em pé para dançar? O excesso...

Reflito sobre o olhar que estranha as coisas do mundo assim como os lugares há muito habitados e que retorna como sensação de horror, olhar que se mira, olhar que se estranha, - porque não está contido especularmente -, nome que não se reconhece. Sujeito a estranhar/entranhar-se. Ficarei em pé para dançar?

A fantasmagoria, os olhos fechados, a experimentação de um olho vazio de olhar, que na perda do enquadre instaura uma ausência de si. Olho sem olhar que atravessa e desaloja a moldura de um dançar. Desaloja também o sujeito de seu Heim? Ficarei em pé para dançar?

Lacan, numa passagem do Seminário 10, intitulado "A angústia", assim se refere ao Heim: "Digamos que, se essa palavra tem algum sentido na experiência humana, é o da casa do homem... O homem encontra sua casa num ponto situado no Outro para além da imagem de que somos feitos... Esse lugar representa a ausência em que estamos". (LACAN, 2005, p. 153). Ficarei em pé para dançar?

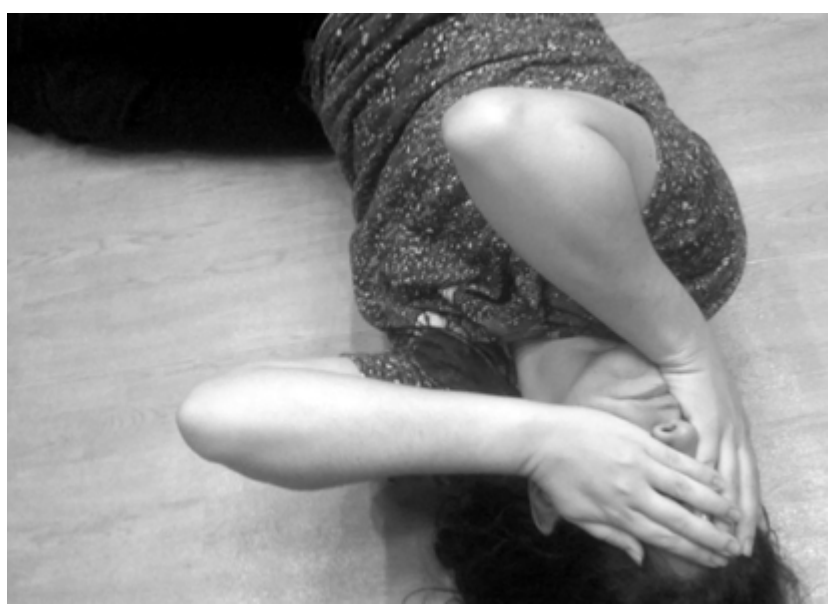

Figura 3. Processo de criação do Estudo nº 01: Persefonia. Foto: Vivian Barbosa. Na foto: Carla Andrea Lima. 
Lacan situa a angústia como correlativa desse excesso, experimentado como Unheimilich, decorrente de uma invasão disso que cai da imagem corporal como traço não especularizável. O corpo do excesso, sem suporte especular encena, tal como salienta Ana Costa, a passagem do lar à coisa. A coisa pensada aqui como o excesso excluído da articulação da palavra. Entretanto, é a mesma Ana Costa que nos coloca, como especificidade do campo da arte, um saber fazer com isso que resta excessivo, excluído como um ponto de perda. Ponto esse em que o sujeito não se (re)conhece. Ficarei em pé para dançar?

Um suporte, um apelo. Letra, litura, amarração. Na busca por esse saber fazer com o que resta do corpo, de suportar esses restos de si que se presentificavam como dança fez-se necessária uma travessia e com ela, juntamente com a necessidade de produzir uma escrita e, em suma, produzir um "leitor", pensado aqui como alguém que acolha e, por sua vez, testemunhe esse excesso presentificado em ato, ato de dança. E para su-portar essa queda, esse luto, convoquei como testemunha, Vivian Barbosa, que me ancorou onde eu me desconhecia. Ficarei em pé para dançar?

Essa questão fantasmática perpassou todo o processo de criação do solo intitulado "Persefonia" que, desde o início operou com o chamamento/poema de Manoel de Barros conjuntamente com as derivações de uma figura: Perséfone. Penso então no rapto, na queda de Perséfone e ainda em seu duplo, Core, seu nome anterior ao rapto. Nome dado pelo outro, como todo nome.

O que dizer da cegueira de todo sujeito em relação a seu nome? Do nome próprio sabemos que ele não significa nada, mas representa um lugar com o qual o sujeito tem que se haver e o qual ele desconhece. Lugar que diz respeito a uma série de representações que esse sujeito tem no olhar daqueles que o receberam e o nomearam. Ou seja, não é certo que, uma vez dado um nome, o sujeito o sustente, haja vista que sustentá-lo é cavar um lugar, uma posição diante desse Outro. E sabemos que marcar essa posição pressupõe o encontro com um esvaziamento.

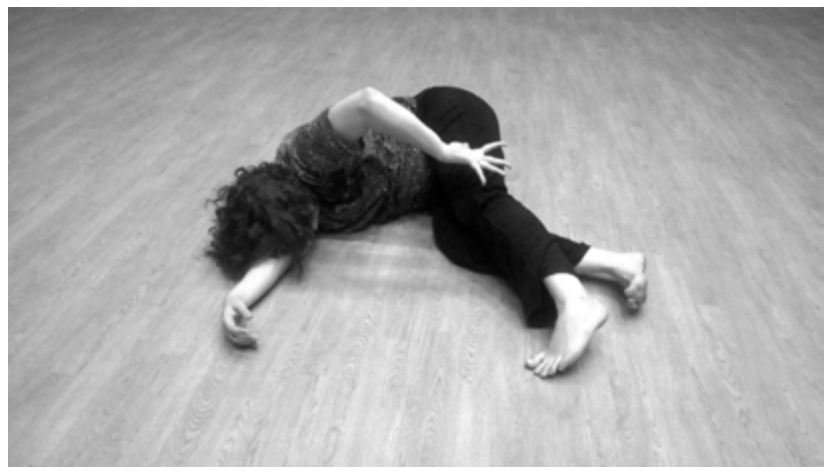

Figura 4.

Processo de criação do Estudo no 01: Persefonia. Foto: Vivian Barbosa. Na foto: Carla Andrea Lima 
Tomo o corpo como lugar em que algo se cava. Algo que faz índice, que faz amarração no lugar de um esvanecimento. Amarração que, para a psicanálise, se constrói nas bordas pulsionais, na relação com o Outro e que enovela o corpo nessa construção.

Nessa perspectiva, o testemunho busca a reconstituição de uma filiação e memória a partir de um endereçamento, ou seja, a busca do testemunho é a de construir enlaces. De modo que a função do testemunho diz respeito a fazer passar algo que não faz série. Trata-se, portanto, de fazer passar algo que só se presentifica no lacunar, em sua dimensão de furo. O que se afeta nesse estar em "presença de" quando o que se abre é uma dimensão de ausência, de vazio a partir do qual um chamamento de corpo nos dirige ao dançar?

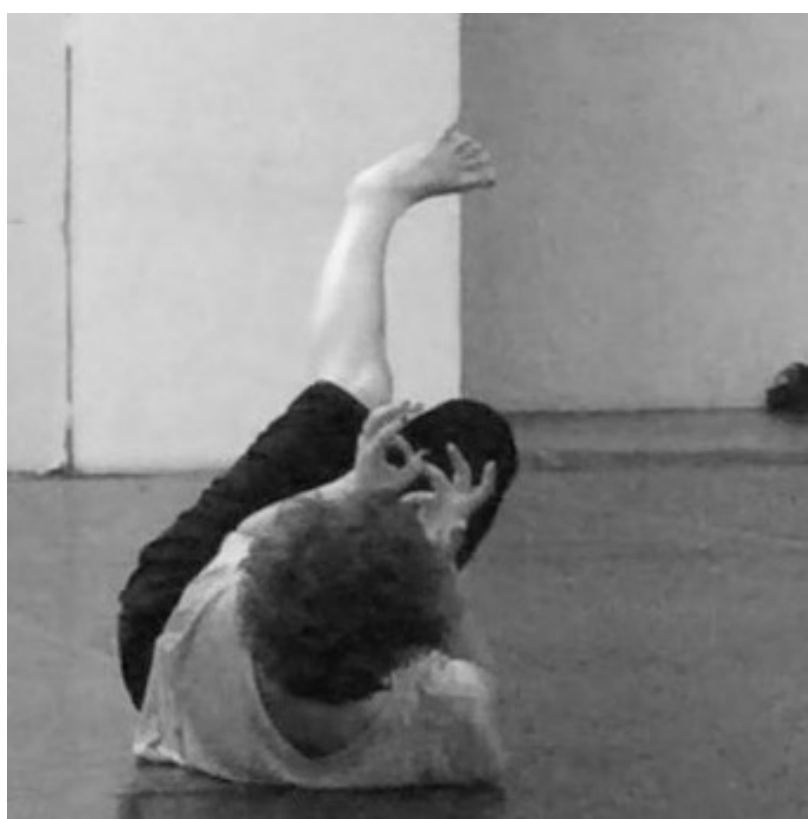

Figura 5.

Processo de criação do Estudo $n^{\circ}$ 01: Persefonia. Foto: Gui Augusto. Na foto: Carla Andrea Lima.

Importante dizer, no tocante a esses encontros, que algo ali não co-respondia, no sentido de que a resposta não vinha na direção antes ansiada, imaginada, metodologizada... O que restava eram fragmentos, medos, vazios. Convém então que eu permaneça aqui firme na companhia de Lacan quando ele defende que a psicanálise prospera no fracasso e sustentar que o processo artístico prospera no fracasso apostando que, partir desses pontos de fuga, um saber se constrói. Exatamente a partir do que rateou, que atuou. De tal modo que a função do outro não se encaixava, nesse trabalho, no recorte/função de diretor, uma vez que não se tratava a princípio de composição, de um olhar que enquadrava determinado campo de visibilidade a partir do recorte cênico. Trata-se antes de um olhar que era apoio, suporte para que a queda não quebrasse, seja pela desfiliação seja pela des-implicação em relação a esse 
ponto desconhecido que chamamos "si" e que traz em seu bojo a dimensão de uma perda, de um luto, que é o trabalho sobre isso que "perdido", ainda subsiste como traço.

De certa forma, o trabalho sobre a memória, ou seja, sobre esses restos e traços, não deixa de avizinhar-se do trabalho de luto. Allouch propõe o luto como relativo a um pedaço de si. O si aqui como um indeterminado, localizado num "entre" lugares: nem bem do sujeito, nem bem do Outro - litoral.

Em "Persefonia" era inevitável o ter que arcar com longos períodos de voltas, volteios em torno do nada, escapes e alinhavos. Nessa travessia era preciso o lidar com a opacidade do próprio fazer apostando -sem garantias - no endereçamento dessa fala muda para alguém.

Diante desse endereçamento mudo, restou o testemunho, na tentativa de (su) portar isso que lhe é enviado com e pelo corpo. É nesse sentido que só existe testemunho em presença, visto que, nessa partida com o silêncio, não se trata de falar sobre a experiência, de dizer o que aquilo quer dizer. Trata-se de oferecer o corpo em presença/ausência de si transitando nesse espaço de borda, luminoso e estranho que é o do encontro com o Outro - um encontro entre heterogêneos e, portanto, um encontro na diferença. Operar uma travessia pelo testemunho pressupõe convocar o corpo para que se possa suportar que é a partir dos rastros que o sujeito constrói, pela via do testemunho, uma escrita. Retoma-se que a escrita, tal como a psicanálise a recorta, como conceito, trata de escrita como manejo da letra, do significante quando este opera em sua dimensão de furo, ressoando no corpo como um acontecimento.

O testemunho nos revela que o Outro existe, e que se por um lado ele nos captura em sua rede no momento em que nos constitui, por outro, é espaço de travessia, tendo em vista que é por meio do quadro fantasmático que podemos sofrer os efeitos do que nele se vela e revela. Esse quadro fantasmático sustenta-se a partir do que nele resta obliterado, ou seja, o objeto a. Objeto não especularizável, elidido do quadro. Objeto perdido que sustenta nossa imagem como eu e como corpo.

Sob esse prisma, podemos pensar que o que se coloca aqui não é da ordem da fuga dos planos de visibilidade, ou ainda de sentido, mas de mudança de posição que pressupõe a criação, no que ela se avizinha com uma produção de uma inscrição singular do sujeito, em torno do que se cria/perde. Nesse aspecto, é no encontro com o Outro que uma nova amarração, um novo enlaçamento pode se fazer contornando esse objeto perdido e constituindo nessa travessia a inscrição de uma diferença. É da inscrição dessa diferença, que decorre da experiência singular do sujeito que se dá a modificação 
dos limites de cada campo fazendo com que fronteiras sejam franqueadas, gêneros sejam misturados e "especialistas" derrubados.

Defendo que essa inscrição, quando dança, é marca, litura de um saber fazer com o Real que se ancora num acontecimento de corpo o que também acarreta o franqueamento de fronteiras no tocante aos saberes sobre corpo e dança.

Tal como salienta Clarice Lispector:

[...] a matéria do corpo antecede o corpo, e por sua vez a linguagem um dia terá antecedido a posse do silêncio. Eu tenho a medida que designo - e este é o esplendor de se ter uma linguagem. Mas eu tenho muito mais à medida que não consigo designar. A realidade é a matéria-prima, a linguagem é o modo como eu vou buscá-la e como não acho. Mas é do buscar e não achar que nasce o que eu não conhecia, e que instantaneamente reconheço. A linguagem é o meu esforço humano. [...] Só quando falha a construção, é que obtenho o que ela não conseguiu. E é inútil procurar encurtar o caminho e querer começar já sabendo que a voz diz pouco, já começando por ser despessoal. Pois existe a trajetória, e a trajetória não é apenas um modo de ir. A trajetória somos nós mesmos. Em matéria de viver, nunca se pode chegar antes. A via crucis não é um descaminho, é a passagem única, não se chega senão através dela e com ela. A insistência é o nosso esforço (LISPECTOR, 1998, p. 17)

O que defendo nessa escrita não é da ordem de uma pragmática, da descrição de metodologias a serem seguidas no tocante aos processos de criação, mas antes a procura por uma escuta que não se prende a um lugar estável de enunciação. O que proponho aqui é uma escuta errante - posto que tem que lidar com essa dupla inscrição do objeto a de ser encontrado porque resta irremediavelmente perdido. 


\section{REFERÊNCIAS}

ALVARENGA, Elisa. O sintoma contra o sentido. Opção Lacaniana - Revista Brasileira Internacional de Psicanálise, $n^{\circ}$ 36. São Paulo: Edições Eolia, 2003. p. 71-73. COSTA, Ana. Corpo e Escrita: relações entre memória e transmissão da experiência. Rio de Janeiro: Relume Dumará, 2001. ISBN 9788573162660 .

COSTA, Ana. Litorais da psicanálise. São Paulo: Escuta, 2015, 218p. ISBN 9788571373662.

DIDI-HUBERMAN, Georges. O que vemos, o que nos olha. São Paulo: Editora 34, 2010, 259p. ISBN 9788573261134.

DUNKER, Christian. "Prefácio". In: Litorais da psicanálise. São Paulo: Escuta, 2015, 218p. ISBN 9788571373662.

FOUCAULT, Michel. "A vida dos homens infames". Les cahiers du chemin, $n^{\circ} 29,1977$.

FREUD, Sigmund. ESB. v. XVII. Rio de Janeiro: Imago, 1996

LACAN, Jacques. "A direção do tratamento e os princípios de seu poder”. In: Escritos. Tradução de Vera Ribeiro. Rio de Janeiro: Zahar, 1998, 944p. ISBN 8571104433.

LACAN, Jacques. "Lituraterra". In: Outros escritos. Tradução de Vera Ribeiro. Rio de Janeiro: Zahar, 2003, 608p. ISBN 8571107513. LACAN, Jacques. "O aturdido". In: Outros escritos. Rio de Janeiro: Zahar, 2003, 608p. ISBN 8571107513.

LACAN, Jacques. "O rato no labirinto" [1973]. In: O seminário, livro 20: Mais, ainda. Rio de Janeiro: Jorge Zahar, 1985, 201p. ISBN 8571104913 .

LACAN, Jacques. O saber do psicanalista [1971-72]. Recife: Centro de Estudos Freudianos do Recife (publicação para circulação interna), 1997.

LACAN, Jacques. O seminário, livro 10: a angústia (1959-1960). Rio de Janeiro: Zahar, 2005, 368p. ISBN 8571108862

LAURENT, Eric. O nome do Pai entre realismo e nominalismo. Opção Lacaniana - Revista Brasileira Internacional de Psicanálise, $n^{\circ}$ 58. São Paulo: Edições Eolia, 2010.

LIMA, Carla Andrea. Corpo, pulsão e vazio: uma poética da corporeidade. 2012. Tese (Doutorado em Artes) - Escola de Belas Artes, Universidade Federal de Minas Gerais, Belo Horizonte, 2012.

LISPECTOR, Clarice. A paixão segundo G.H. Rio de Janeiro: Rocco, 1998. MANDIL, Ram. "James Joyce e a ideia de si como corpo". Anais do XI Congresso Internacional da ABRALIC: Tessituras, Interações, Convergências. São Paulo: USP, 2008. Disponível em: http://www. abralic.org.br/eventos/cong2008/AnaisOnline/simposios/pdf/005/ RAM_MANDIL.pdf. Acesso em: 01 mar.2017. 
NAIDIN, Julia. "Vidas heterotópicas, vidas infames, vidas outras: um percurso antropológico do pensamento de Foucault. Revista Filosofia Aurora, v. 28, n. 45, p. 1027-1048, set-dez. 2016.

QUILICI, Cassiano. "A experiência da não forma e o trabalho do ator". In: $\mathbf{O}$ ator-performer e as poéticas de transformação de si. São Paulo: Annablume, 2015, 228p. ISBN 9788539107063.

PESSANHA, Juliano Garcia. Testemunho Transiente. São Paulo: Cosac Naify, 2015, 320p. ISBN 8540509695.

KEHL, Maria Rita. "Prefácio". In: Corpo e Escrita: relações entre memória e transmissão da experiência. Rio de Janeiro: Relume Dumará, 2001. ISBN 9788573162660. 